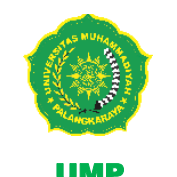

NERACA

JURNAL PENDIDIKAN EKONOIMI

http://journal.umpalangkaraya.ac.id/index.php/neraca

Volume 6 Nomor 1, November 2020 (22-29)

\title{
UPAYA PENERAPAN PEMBELAJARAN KOOPERATIF DENGAN METODE THINK PAIR SHARE UNTUK MENINGKATKAN MOTIVASI BELAJAR MATA PELAJARAN IPS PADA SISWA KELAS IV SD NEGERI 1 SAMBA DANUIM \\ Efforts To Implement Cooperative Learning With The Think Pair Share Method To Increase Motivation In IPS Lesson Learning In Grade IV Students Of SD Negeri 1 Samba Danum \\ Erniwatie
}

SD Negeri I Samba Danum, Katingan, Kalimantan Tengah, Indonesia

\section{ARTIKEL INFO}

Diterima

September 2020

Dipublikasi

November 2020

*e-mail :

rikuatnospd@yahoo.co.id

\section{ABSTRAK}

Hasil penelitian yang dilakukan secara kolaborasi antara peneliti dengan guru kelas IV SD Negeri I Samba Danum menyatakan bahwa terjadi peningkatan motivasi belajar hal-hal yang menjadi indikator motivasi belajar siswa yaitu meliputi: I) perhatian siswa terhadap penjelasan guru, 2) keberanian siswa dalam bertanya, dan 3) keberanian siswa dalam menjawab pertanyaan, serta peningkatan hasil belajar siswa yang menjadi indikator hasil belajar yaitu nilai hasil belajar siswa yang diketahui setelah diadakan tes di setiap akhir pelajaran. Pembelajaran yang menggunakan metode Think Pair Share terbukti mampu meningkatkan motivasi belajar siswa serta berdampak pada peningkatan hasil belajar siswa kelas IV SD Negeri I Samba Danum pada pelajaran IPS. Proses pembelajaran melalui metode Think Pair Share yang di terapkan oleh peneliti dengan lebih mengaktifkan siswa dan sepenuhnya proses pembelajaran berpusat pada siswa. Dengan asumsi bahwa semua resitasi atau diskusi membutuhkan pengaturan untuk mengendalikan kelas secara keseluruhan, dan prosedur yang digunakan dalam metode Think Pair Share dapat memberi siswa lebih banyak waktu berpikir, untuk merespon dan saling membantu. Pembahasan hasil penelitian ini dibuktikan bahwa dari 15 siswa hanya 6 siswa yang termotivasi dengan prosentase $40 \%$ setelah diterapkan metode Think Pair Share naik menjadi 14 siswa dengan prosentase 93,33\%. Dengan demikian dapat disimpulkan metode Think Pair Share dapat meningkatkan motivasi belajar siswa pada mata pelajaran IPS pada siswa kelas IV SD Negeri I Samba Danum terbukti kebenarannya.

Kata kunci: Pembelajaran Kooperatif, Metode Pair Think Share, Motivasi Belajar, Mata Pelajaran IPS

\section{ABSTRACT}

The results of the research conducted in collaboration between the researcher and the fourth grade teacher of SD Negeri I Samba Danum stated that there was an increase in learning motivation. and 3) students' courage in answering questions, as well as improving student learning outcomes which are indicators of learning outcomes, namely the value of student learning outcomes that are known after a test is held at the end of each lesson. Learning using the Think Pair Share method is proven to be able to increase student motivation and have an impact on improving the learning outcomes of fourth grade students of SD Negeri I Samba Danum in social studies lessons. The learning process through the Think Pair Share method which is applied by researchers to further activate students and fully student-centered learning process. Assuming that all recitation or discussion requires arrangements to control the class as a whole, and the procedures used in the Think Pair Share method can give students more time to think, to respond and to help each other. The discussion of the results of this study proved that out of 15 students only 6 students were motivated with a percentage of $40 \%$ after the Think Pair Share method was applied, it increased to 14 students with a percentage of $93.33 \%$. Thus it can be concluded that the Think Pair Share method can increase student motivation in social studies subjects in grade IV SD Negeri I Samba Danum proven to be true.

Keywords: Cooperative Learning, Pair Think Share Method, Learning Motivation, Social Studies Subjects 


\section{PENDAHULUAN}

Pendidikan adalah tujuan sadar yang bertujuan untuk mengembangkan kualitas manusia, sebagai sesuatu kegiatan yang sadar akan tujuan, maka di dalam pelaksanaannya berada dalam suatu proses yang berkesinambungan dalam setiap jenis dan jenjang pendidikan semuanya berkaitan dalam suatu sistem pendidikan yang integral Djamarah (dalam lin angraeni. 2009: I) . Ada dua konsep pendidikan yang saling berkaitan yaitu belajar (Learning) dan pembelajaran (Instruction). Konsep belajar berakar pada pihak pendidik. Tujuan pendidikan adalah membentuk sumber daya manusia yang berkualitas tinggi yaitu manusia yang mampu menghadapai perkembangan zaman.

Guna mencapai tujuan pendidikan tersebut diperlukan proses pendidikan. Pendidikan dapat ditempuh melalui jalur formal dan nonformal. Pendidikan formal merupakan pendidikan yang dimulai dari jenjang terendah hingga tertinggi yang harus ditempuh dengan serangkaian persyaratan tertentu jika akan naik ke jenjang selanjutnya. Pendidikan nonformal merupakan jenjang pendidikan yang di peroleh dalam sebuah lembaga pendidikan yang beorientasi memberi dan meningkatkan ketrampilan yang dibutuhkan untuk berkompetisi dalam meraih kesuksesan hidup.

Hasil belajar merupakan tolok ukur yang utama untuk mengetahui keberhasilan belajar seseorang. Seorang yang prestasinya tinggi dapat dikatakan bahwa ia telah berhasil dalam belajar. Menurut Nasution dalam (Wartiningsih, 2010: 12) Prestasi belajar adalah Penguasaan seseorang terhadap pengetahuan dan ketrampilan tertentu dalam suatu mata pelajaran yang semestinya diperoleh dari nilai tes/angka yang diberikan guru.

Metode pembelajaran Think Pair Share merupakan metode yang sangat baik di gunakan untuk melibatkan peserta didik dalam mempelajari materi yang telah disampaikan.

Peneliti ingin meningkatkan motivasi belajar siswa yang menggunakan pembelajaran kooperatif tipe Think Pair Share. Think Pair Share merupakan jenis metode pembelajaran kooperatif yang dirancang untuk mempengaruhi pola interaksi siswa. Struktur yang dimaksudkan sebagai alternatif pengganti terhadap struktur kelas tradisional. Struktur ini menghendaki siswa bekerja saling membantu dalam kelompok kecil (2-6 anggota). Think Pair Share memiliki prosedur yang ditetapkan secara eksplisit untuk memberi siswa waktu yang lebih untuk berpikir, menjawab dan saling membantu satu sama lainnya.

Adapun tujuan penelitian ini untuk meningkatkan motivasi belajar siswa pada mata pelajaran IPS melalui pembelajaran kooperatif dengan menggunakan metode Think Pair Share pada siswa kelas IV SD Negeri I Samba Danum.

Pembelajaran kooperatif adalah konsep yang lebih luas meliputi semua jenis kerja kelompok termasuk bentuk-bentuk yang lebih dibimbing oleh guru atau diarahkan oleh guru. Secara umum pembelajaran kooperatif diangggap lebih diarahkan oleh guru, dimana guru menetapkan tugas dan pertanyaan pertanyaan serta menyediakan bahan informasi yang dirancang untuk membantu peserta didik menyelesaikan masalah yang dimaksud.

Adapun unsur pembelajaran kooperatif di antaranya :

I. Setiap anggota kelompok bertanggung jawab atas segala sesuatu yang dikerjakan dalam kelompoknya.

2. Setiap kelompok harus mengetahui bahwa semua anggota kelompok mempunyai tujuan yang sama.

3. Setiap kelompok harus membagi tugas dan tanggung jawab yang sama diantara anggota kelompoknya. 
Jurnal Pendidikan Ekonomi

4. Setiap anggota kelompok akan dikenai evaluasi.

5. Setiap kelompok saling berbagi kepemimpinan dan membutuhkan keterampilan untuk belajar bersama selama proses belajarnya.

6. Setiap anggota kelompok akan diminta bertanggung jawab secara individual.

7. Materi yang ditangani dalam kelompok kooperatif.

Situasi pembelajaran kooperatif di dorong dan atau dituntut untuk bekerja sama dalam suatu tugas bersama, siswa harus mengoordinasikan usaha-usahanya untuk menyelesaikan tugas. Pada pembelajaran kooperatif dua atau lebih individu saling tergantung untuk suatu penghargaan apabila mereka berhasil sebagai suatu kelompok.

Metode Think Pair Share (TPS) merupakan salah satu strategi dalam pembelajaran kooperatif yang dapat memberikan waktu kepada siswa untuk berpikir sehingga strategi ini punya potensi kuat untuk memberdayakan kemampuan berpikir siswa. Peningkatan kemampuan berpikir siswa akan meningkatkan hasil belajar atau prestasi belajar siswa dan kecakapan akademiknya.

Berdasarkan kajian teori yang telah dikemukakan diatas, maka dapatlah disusun suatu kerangka pemikiran guna memperoleh kesimpulan sementara dari apa yang akan diteliti. Dalam suatu kegiatan belajar mengajar, metode pembelajaran yang digunakan guru tidak selamanya akan menghasilkan hasil yang baik. Karena tingkat intelegensi setiap siswa berbeda-beda. Untuk merangsang perhatian siswa dalam mempelajari materi yang belum dikuasai serta membuat siswa tidak merasa bosan dalam merpelajari materi yang diberikan oleh guru, perlu adanya metode pembelajaran yang tepat sehingga proses pembelajaran IPS dapat berlangsung dengan baik, berhasil dan menyenangkan.

Pembelajaran Think Pair Share memiliki langkah-langkah yang sederhana dan mudah diterapkan dalam pembelajaran. Metode Think Pair Share ini memberikan kesempatan siswa dapat belajar dengan teman sebaya yang akan melatih kerjasama dalam belajar, berfikir, menjawab, dan saling membantu satu sama lain. Pembelajaran kooperatif tipe Think Pair Share ini diharapkan memberikan keberartian pengalaman belajar pada siswa dan berimplikasi positif terhadap hasil belajar siswa. Hubungan siswa, metode pembelajaran dan hasil belajar ditunjukkan dengan ilustrasi kerangka pemikiran. Skema ilustrasi kerangka pemikiran dapat dilihat dibawah ini:

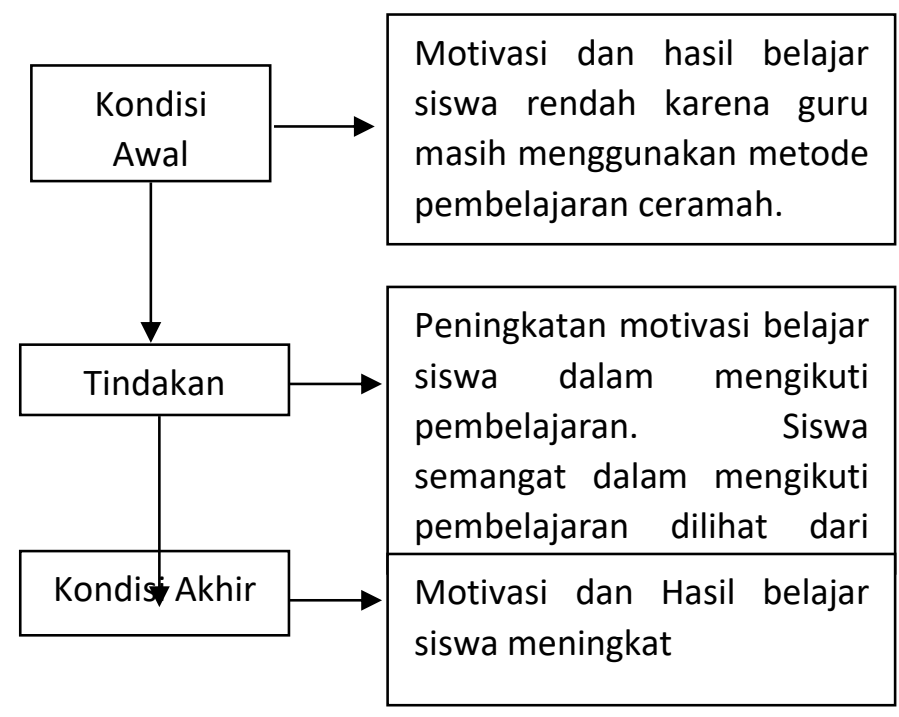

\section{METODE PENELITIAN}

Suatu penelitian memerlukan tempat penelitian yang akan dijadikan obyek untuk memperoleh data-data yang berguna untuk mendukung tercapainya tujuan penelitian. Penelitian ini dilakukan di SD Negeri I Samba Danum.

Penelitian penerapan metode Think Pair Share untuk meningkatkan hasil belajar mata pelajaran IPS pada siswa di kelas IV SD Negeri I Samba Danum dengan waktu pelaksanaan pada bulan Oktober-Desember 2017. 
Jurnal Pendidikan Ekonomi

Penelitian ini merupakan penelitian tindakan kelas (PTK) istilah dalam bahasa Inggris adalah Classroom Action Research (CAR), yaitu upaya peningkatan hasil belajar IPS kelas IV di SD Negeri I Samba Danum dengan metode Think Pair Share yang dilakukan melalui proses kerja kolaborasi antara guru kelas dan peneliti. Dalam penelitian tindakan kelas, peneliti melakukan sesuatu tindakan secara khusus diamati terus menerus, kemudian diadakan perubahan terkontrol sampai pada upaya maksimal dalam bentuk tindakan yang paling tepat (Arikunto, 2007: 2). Penelitian tindakan kelas ini merupakan kegiatan pemecahan masalah yang dimulai dari: a). Perencanaan (planning), b). Tindakan (action), c). Observasi, d). Refleksi.

Menurut Rubiyanto (2009: I20) prosedur Penelitian Tindakan Kelas (PTK) merupakan penelitian bersiklus yang terdiri dari empat langkah yaitu dialog awal, perencanaan (planning), tindakan (action), observasi dan monitoring (observation), refleksi (reflection,), evaluasi dan penyimpulan yang dilakukan secara berulang.

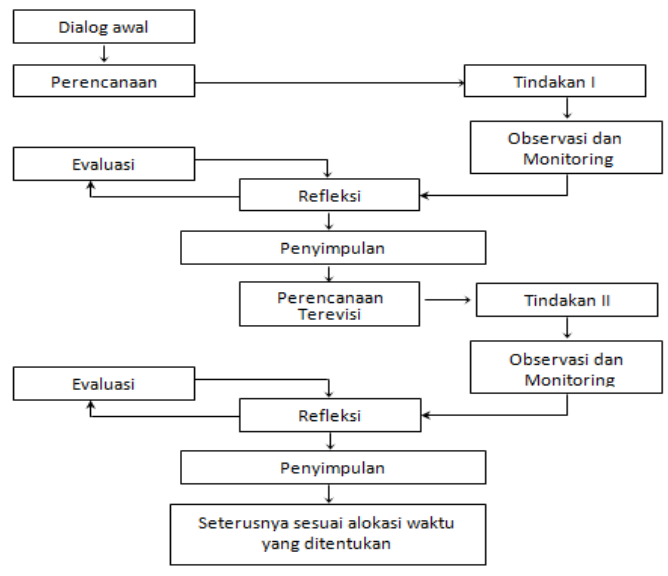

Jenis data dalam penelitian disini adalah sebagai berikut:

I. Data Kuantitatif (nilai hasil belajar siswa) dapat dianalisis secara deskriptif. Dalam hal ini peneliti menggunakan analisis statistik untuk mencari nilai rata-rata dan presentase keberhasilan belajar.

2. Data Kualitatif, yaitu data yang berupa informasi berbentuk kalimat yang memberikan gambaran tentang ekspresi pesertadidik berkaitan dengan tingkat pemahaman sesuatu terhadap mata pelajaran, baik dari aspek kognif, afektif maupun psikomotornya. Peneliti menggunakan data kualitatif untuk menggabarkan motivasi siswa dalam mengikuti pembelajaran IPS.

Sumber data dalam PTK ini adalah siswa untuk mendapatkan data tentang motivasi belajar siswa dalam proses belajar mengajar.Kemudian guru untuk melihat tingkat keberhasilan penerapan metode Think Pair Share dan motivasi belajar siswa dalam proses belajar mengajar. Selanjutnya teman sejawat dan kolaborator

Teman sejawat dan kolaborator dimaksudkan sebagai sumber data untuk melihat implementasi PTK secara komprehensif, baik dari sisi siswa maupun guru.

Metode pengumpulan data adalah prosedur yang sistematik dan standar untuk memperoleh data yang diperlukan (Nazir, 1999: 2II). Untuk memperoleh data dikelas secara konkrit, maka penulis mengadakan penelitian menggunakan metode observasi, dokumentasi, wawancara, dan tes.

Pengujian validitas data menggunakan validitas triangulasi. Menurut Sugiyono dalam (Nela, 2011: 39-40) triangulasi adalah pengecekan data dari berbagai sumber dengan berbagai cara dan berbagai waktu. Validitas triangulasi dalam pengujian data dilakukan dengan tiga cara yaitu triangulasi sumber, triangulasi teknik, dan triangulasi waktu.

Analisis data Penelitian Tindakan Kelas menurut model Miles dan Huberman (dalam Putera. 20II: 204) setelah pengumpulan data dapat di tindak lanjuti dengan: 
I. Reduksi Data

Reduksi data merupakan proses pengumpulan data penelitian, memilih hal-hal yang pokok, memfokuskan pada hal-hal yang penting.

\section{Display/Penyajian Data}

Dengan display/penyajian data, maka akan memudahkan untuk memahami apa yang terjadi, merencanakan kerja selanjutnya berdasarkan apa yang telah dipahami.

3. Penarikan Kesimpulan

Penarikan kesimpulan adalah merupakan temuan baru yang sebelumnya belum pernah ada. Temuan dapat berupa deskripsi atau gambaran suatu objek yang sebelumnya masih abstrak sehingga setelah diteliti menjadi jelas, dapat berupa hubungan interaktif, hipotesis atau teori.

Indikator keberhasilan dalam penelitian ini diharapkan ada peningkatan motivasi belajar siswa, sekurang-kurangnya $75 \%$ siswa termotivasi dalam pembelajaran IPS. Indikator motivasi dalam penelitian ini yaitu: I) perhatian siswa terhadap materi pelajaran yang telah di sampaikan oleh guru $75 \%, 2$ ) keberanian siswa dalam mengajukan pertanyaan $75 \%$, dan 3) keberanian siswa dalam menjawab pertanyaan $75 \%$.

\section{HASIL PENELITIAN PEMBAHASAN}

\section{Pra Siklus}

Peneliti mengadakan dialog awal dengan kepala sekolah dan guru kelas IV untuk mengetahui kondisi awal siswa dalam proses pembelajaran IPS. Dari dialog awal di dapat rumusan masalah sebagai berikut: "Apakah pembelajaran kooperatif dengan metode Think Pair Share dapat meningkatkan motivasi belajar siswa mata pelajaran IPS pada siswa kelas IV SD Negeri I Samba Danum ?".

Berdasarkan nilai hasil belajar siswa pada pra tindakan maka dapat disimpulkan siswa yang tuntas belajar sebanyak 6 siswa
(40\%) siswa yang tuntas belajar dan siswa yang belum tuntas sebanyak 9 siswa (60\%).

Dengan adanya permasalahan yang muncul maka peneliti dan guru kelas berkolaborasi untuk memperbaiki permasalahan dalam pembelajaran IPS dengan menggunakan metode Think Pair Share. Metode ini di harapkan dapat meningkatkan motivasi belajar siswa pada mata pelajaran IPS. Berdasarkan observasi kondisi awal di peroleh hasil belajar siswa kelas IV SD Negeri I Samba Danum pada pelajaran IPS.

\section{Siklus I ( $2 \times$ pertemuan)}

Pelaksanaan penelitian tindakan siklus I di laksanakan pada tanggal 6 November 2017 penelitian di lakukan dengan empat tahap yaitu : perencanaan (planning), tindakan (acting), observasi (observing) dan refleksi (reflekting). Guru menerapkan metode Think Pair Share pada siklus I dan mengadakan tes pada setiap akhir pembelajaran untuk mengetahui hasil belajar siswa pada pelajaran IPS.

Hasil belajar siklus I pada pertemuan pertama dan pertemuan kedua diperoleh rata-rata kelas mengalami peningkatan yaitu 70. Serta terdapat 8 siswa telah mencapai $K K M \geq 65$ atau $53,33 \%$.

\section{Siklus II ( $2 \times$ Pertemuan)}

a. Perencanaan

Perencanaan kegiatan pembelajaran pada siklus II berkaitan dengan pembelajaran pokok materi kegiatan manusia yang mengubah permukaan bumi. Dengan alokasi waktu $4 \times 35$ (4 Jam Pertemuan) selama dua kali pertemuan.

b. Tindakan

Pelaksanaan kelas siklus II dilaksanakan dua kali pertemuan. Pada siklus II ini pelaku tindakan adalah peneliti dan dibantu oleh guru kelas IV pada pelajaran IPS. Selain membantu peneliti dalam kegiatan pembelajaran di kelas, guru juga melakukan observasi dan monitoring terhadap hasil belajar siswa.

\section{c. Tindakan}


Dapat di ambil dari keseluruhan tindakan yang telah dilaksanakan pada siklus II yang telah dilaksanakan selama dua kali pertemuan dari 25 siswa, rata-rata siswa yang termotivasi sebanyak 14 siswa (93,33\%). Sehingga penelitian ini sudah dikatakan berhasil pada siklus II. Sehingga dapat meningkatkan motivasi belajar siswa pada siklus II, serta hasil belajar siswa sama sebanyak 14 siswa dan sudah mencapai indikator pencapaian yang telah di tetapkan dalam penelitian ( $75 \%$ siswa termotivasi).

Hasil peningkatan motivasi belajar siswa observasi tentang aspek penunjang hasil belajar siswa di peroleh beberapa keterangan atau gambaran mulai dari pra tindakan, siklus I dan siklus II. Adapun yang menjadi indikator penunjang hasil belajar siswa adalah I) perhatian siswa terhadap penjelasan guru, 2) keberanian siswa dalam bertanya, dan 3) keberanian siswa dalam menjawab pertanyaan.

Nilai rata-rata pelajaran IPS dengan menggunakan metode pembelajaran Think Pair Share pada siswa kelas IV SD Negeri I Samba Danum sebelum tindakan/pra siklus yang hanya menerapkan metode konvensional yaitu sebesar 55 ( 6 siswa mencapai KKM dengan prosentase $40 \%$ ). Pada siklus I menggunakan metode Think Pair Share rata-rata menadi 63 (9 siswa yang mencapai KKM dengan prosentase $60 \%$ ). Setelah dilakukan perbaikan pada siklus II rata-rata hasil belajar menadi 70 ( 14 siswa yang mencapai KKM dengan prosentase $93,33 \%$ ).

Pembahasan terhadap permasalahan penelitian maupun hipotesis tindakan dilakukan berdasarkan analisis data hasil penelitian dari kolaborasi antara peneliti dan tanggapan guru kelas IV SD Negeri I Samba Danum pada mata pelajaran IPS. Beberapa hal yang di jelaskan dalam permasalahan adalah sesuatu yang berkaitan dengan hipotesis tindakan. Selama proses penelitian, tindakan yang dilakukan oleh peneliti dalam proses pembelajaran IPS adalah untuk meningkatkan motivasi belajar siswa melalui metode Think Pair Share.

Pembahasan hasil penelitian ini dibuktikan bahwa dari I 5 siswa hanya 6 siswa yang termotivasi dengan prosentase $40 \%$ setelah diterapkan metode Think Pair Share naik menjadi I4 siswa dengan prosentase 93,33\%. Dengan demikian dapat disimpulkan metode Think Pair Share dapat meningkatkan motivasi belajar siswa pada mata pelajaran IPS pada siswa kelas IV SD Negeri I Samba Danum .

\section{KESIMPULAN}

Berdasarkan hasil penelitian tindakan kelas yang dilakukan secara kolaborasi antara peneliti dan guru kelas IV dalam upaya meningkatkan motivasi belajar siswa pada mata pelajaran IPS melalui penerapan metode Think Pair Share selama dua siklus dapat disimpulkan bahwa penerapan metode think pair share dapat meningkatkan motivasi belajar pada siswa kelas IV SD Negeri I Samba Danum pada mata pelajaran IPS yang dilihat pada observasi awal, 6 siswa dengan prosentase $40 \%$ menjadi I4 siswa dengan prosentase $93,33 \%$. Hasil belajar siswa tersebut dapat di simpulkan bahwa penerapan metode Think Pair Share dapat meningkatkan motivasi belajar siswa pada mata pelajaran IPS kelas IV SD Negeri I Samba Danum dirumuskan dapat diterima kebenaranya. Berdasarkan hasil penelitian ini terbukti metode pembelajaran think pair share dapat meningkatkan motivasi belajar siswa kelas IV SD Negeri I Samba Danum Sehubungan dengan penelitian ini maka dapat dikemukakan implikasi memberikan alternatif bagi guru untuk menggunakan metode think pair share untuk meningkatkan hasil belajar siswa khusunya mata pelajaran IPS dan mata pelajaran yang lain pada umunya. Kemuadian menunjukkan pentingnya menggunakan metode pembelajaran yang bervariasi dan 
Jurnal Pendidikan Ekonomi

inovatif, salah satunya adalah metode think pair share yang sudah terbukti dapat meningkatkan hasil belajar siswa mata pelajaran IPS kelas IV SD Negeri I Samba Danum.

\section{DAFTAR PUSTAKA}

Arikunto, Suharsimi. 2006. Prosedur Penelitian Suatu Pendekatan Praktek, XIII. Jakarta: Rineka Cipta.

Arikunto, Suharsimi Dkk. 2007. Penelitian Tindakan Kelas. Jakarta: Bina Aksara.

Asmani Jamali, Ma'mur. 20II. 7 Tips Aplikasi PAKEM. Jogjakarta: IKAPPI.

Endah Neni Mastuti. Meningkatkan Hasil Belajar Biologi Dengan Model Pembelajaran Kooperatif Tipe TPS (Think Pair Share) Pada Siswa Kelas VIII D SMP Negeri 2 Gondang Sragen Tahun Pelajaran 2008/2009. Skripsi. Surakarta : Universitas Muhammadiyah Surakarta.

Hamalik, Oemar. 20II. Kurikulum dan Pembelajaran. Jakarta: Bumi Aksara.

Hartanti, Jana Dwi. 20ll. Peningkatan Aktivitas dan Hasil Belajar IPS Melalui Metode Think Pair Share Pada Siswa Kelas IV SD Negeri 0 I Gantiwarno kecamatan Matesih Kabupaten Karanganyar Tahun Pelajaran 20II/20I2. Skripsi. Surakarta : Universitas Muhammadiyah Surakarta.

lin, Anggraini. 2009. Penerapan Pembelajaran Kooperatif Model TPS (Think Pair Share) Untuk Meningkatkan Hasil Belajar Biologi Siswa Kelas VIII D SMP Muhammadiyah 2 Surakarta Tahun Pelajaran 2008/2009. Skripsi. Surakarta : Universitas Muhammadiyah Surakarta.

Jailani, Muhammad. 2019. Hubungan Status Sosial Ekonomi Orang Tua Terhadap Motivasi Anak Untuk Berwirausaha. Pedagogik: Jurnal Pendidikan I4(I):35-42.
Kasihani. 2009. Model-model Pembelajaran. Universitas Negeri Malang: Panitia Sertifikasi Guru Rayon I5.

Mella Evrilianti R. 20I2. Peningkatan Hasil Belajar Matematika Melalui Metode Pembelajaran Kooperatif Tipe Think Pair Share Bagi Siswa Kelas IV SDN 3 Kalongan Purwodadi Kabupaten Grobogan Tahun Pelajaran 20II/2012. Skripsi. Surakarta : Universitas Muhammadiyah Surakarta.

Nazir. 1999. Metode Penelitian. V. Yogyakarta: Ghalia Indonesia.

Nela Nur Rohimah. 201I. Penerapan Pembelajaran Kooperatif Dengan Metode Think Pair Share Untuk Meningkatkan Motivasi dan Hasil Belajar Siswa Kelas IV MIM Gedongan Pada Mata Pelajaran PKN Tahun Pelajaran 20I0/20II. Skripsi. Surakarta: Universitas Muhammadiyah Surakarta.

Nurhadi. Kurikulum 2004 Pertanyaan Dan Jawaban. Jakarta: PT Gramedia.

Riadin, Agung dan Muhammad Jailani. 2019. Perbedaan Peningkatan Hasil Belajar Ekonomi Dengan Menerapkan Model Cooperatif Tipe NHT (Numbered Head Together) Dan Tipe IOC (Inside Outside Circle) Pada Peserta Didik SMA Muhammadiyah 1 Palangkaraya. Pedagogik: Jurnal Pendidikan 14(2):6070.

Samino dan Saring Marsudi. 20II. Layanan Bimbingan Belajar Pedoman Bagi Pendidik dan Calon Pendidik. Surakarta : Fairus Media

Setiawan, M Andi. 2018. PENELITIAN TINDAKAN KELAS Teori Serta Panduan Bagi Guru Kelas dan Guru Bimbingan Konseling. Yogyakarta: Deepublish.

Rina, Hendri. 2016. Penerapan Model Pembelajaran Kooperatif Tipe Think Pair Share untuk Meningkatkan Hasil Belajar IPS pada SDN-6 Panarung 
Jurnal Pendidikan Ekonomi

Palangka Raya Kelas IVB Tahun

Pelajaran 2014/20I5. Tunas Jurnal

Pendidikan Guru Sekolah Dasar 2(I):2I-

25. 